\title{
THE ROLE OF MELANO-MACROPHAGE AGGREGATES IN THE STORAGE OF MERCURY AND OTHER METALS: AN EXAMPLE FROM YELLOWEYE ROCKFISH (SEBASTES RUBERRIMUS)
}

\author{
Benjamin D. Barst, $\dagger$ Kristin Bridges, $\ddagger$ Malgorzata Korbas,$\S \|$ Aaron P. Roberts, $\ddagger$ Kray Van Kirk,\# \\ Kevin McNeel,\# and Paul E. DrevnicK*††† \\ †INRS-ETE, Université du Québec, Québec, Québec, Canada \\ $\ddagger$ Department of Biological Sciences \& Institute of Applied Sciences, University of North Texas, Denton, Texas, USA \\ $\S$ Canadian Light Source, Saskatoon, Saskatchewan, Canada \\ \|Department of Anatomy and Cell Biology, University of Saskatchewan, Saskatoon, Saskatchewan, Canada \\ \#Division of Commercial Fisheries, Alaska Department of Fish and Game, Douglas, Alaska, USA \\ $\dagger †$ University of Michigan Biological Station and School of Natural Resources and Environment, Ann Arbor, Michigan, USA
}

(Submitted 12 December 2014; Returned for Revision 2 March 2015; Accepted 4 April 2015)

\begin{abstract}
Melano-macrophage aggregates, collections of specialized cells of the innate immune system of fish, are considered a general biomarker for contaminant toxicity. To elucidate further the relationship between macrophage aggregates and metals exposure, yelloweye rockfish (Sebastes ruberrimus), a long-lived species, were sampled from the east and west coasts of Prince of Wales Island, Alaska. Metals concentrations in livers (inorganic $\mathrm{Hg}$, methyl mercury, $\mathrm{Se}, \mathrm{Ni}, \mathrm{Cd}, \mathrm{Cu}, \mathrm{Zn}$ ) and spleens (inorganic $\mathrm{Hg}$ and methyl mercury) were determined, as well as their correlations with melano-macrophage aggregate area. Sections of liver tissue were analyzed by laser ablation-inductively coupled plasma-mass spectrometry to determine how metals were spatially distributed between hepatocytes and macrophage aggregates. The concentration of inorganic $\mathrm{Hg}$ in whole tissue was the best predictor of macrophage area in yelloweye livers and spleens. Macrophage aggregates had higher relative concentrations than most metals compared with the surrounding hepatocytes. However, not all metals were accumulated to the same degree, as evidenced by differences in the ratios of metals in macrophages compared with hepatocytes. Laser ablation data were corroborated with the results of X-ray synchrotron fluorescence imaging of a yelloweye liver section. Hepatic macrophage aggregates in yelloweye rockfish may play an important role in the detoxification and storage of $\mathrm{Hg}$ and other metals. Environ Toxicol Chem 2015;34:1918-1925. (C) 2015 SETAC
\end{abstract}

Keywords: Melano-macrophage aggregates Mercury Metals LA-ICP-MS X-ray fluorescence imaging

\section{INTRODUCTION}

Histopathological biomarkers, such as melano-macrophage aggregates (MA), have been used widely as indicators of contaminant exposure in fish [1]. These aggregates, composed of specialized cells of the innate immune system, can be found in the spleens, kidneys, and livers of teleost fish and often contain pigments such as ceroid, lipofuscin, hemosiderin, and melanin. They serve as repositories for the remains of damaged cells and are thought to be primitive forms of the lymph nodes found in higher vertebrates [2]. Both laboratory and field studies have demonstrated an increased occurrence of MA in fish exposed to various contaminants. They are therefore considered a general biomarker for contaminant toxicity [3]. For example, in a laboratory study, perchlorate was shown to induce MA in the trunk kidneys of zebrafish (Danio rerio) [4], whereas several other studies have demonstrated that metals can lead to increased MA formation [5,6]. Additional evidence that MA are suitable biomarkers of contaminant exposure has been provided by recent field studies. Khan [7] noted increased MA in flatfish inhabiting an environment contaminated with both petroleum and polychlorinated biphenyls. Mercury $(\mathrm{Hg})$, a ubiquitous environmental contaminant deposited from the atmosphere to even the most remote aquatic environments, also has been linked to MA formation. Mela et al. [5] reported

All Supplemental Data may be found in the online version of this article.

* Address correspondence to drevnick@umich.edu.

Published online 9 July 2015 in Wiley Online Library

(wileyonlinelibrary.com).

DOI: $10.1002 /$ etc.3009 increased MA in Hoplias malabaricus fed contaminated methylmercury $(\mathrm{MeHg})$ diets for $70 \mathrm{~d}$. In addition, Raldúa et al. [8] found that feral fish downstream of an $\mathrm{Hg}$ cell chloralkali plant had increased numbers of hepatic MA. An extensive study by Schwindt et al. [9] determined that whole-body $\mathrm{MeHg}$ concentrations were positively correlated with MA in liver and spleens of salmonids from 8 US national parks. The authors also measured more than 90 pesticides and other compounds in 100 brook trout from seven lakes and determined that $\mathrm{Hg}$ explained more than one third of the variation in MA [9]. Further evidence of the link between $\mathrm{Hg}$ and MA in fish was provided by Barst et al. [10], who demonstrated that $\mathrm{Hg}$ and MA were colocalized by analyzing histological sections of spotted gar (Lepisosteus oculatus) liver tissue by laser ablation-inductively coupled plasma-mass spectrometry (LA-ICP-MS). In their study, Barst et al. went beyond identifying statistical correlations by demonstrating that contaminant $(\mathrm{Hg})$ and biomarker (MA) spatially overlapped. Similar findings have been noted for hepatic MA in yellow perch (Perca flavescens) from an $\mathrm{Hg}$ hotspot [11]. This information is especially useful when attempting to assign cause and effect in wild fish, which are exposed to mixtures of contaminants rather than a single chemical.

The main objective of the present study was to determine the relationship between metals and macrophage aggregates in the livers of 2 populations of yelloweye rockfish, a long-lived species, inhabiting the relatively pristine coastal waters of Prince of Wales Island, Alaska. We demonstrate that the concentration of inorganic $\mathrm{Hg}$ in whole tissue is highly correlated with macrophage area in yelloweye livers and 
spleens and that these immune cells accumulate higher relative concentrations of most metals compared with the surrounding hepatocytes. However, not all metals were accumulated to the same degree, as evidenced by 2 in situ imaging techniques (LAICP-MS and X-ray fluorescence).

\section{MATERIALS AND METHODS}

\section{Study sites and sampling}

Yelloweye rockfish are native to the Pacific Coast of the United States and Canada and are part of important recreational and commercial fisheries in the North Pacific [12,13]. Yelloweye were selected for the present study because they are extremely long-lived fish (oldest specimen $>120 \mathrm{yr}$ ) [12] and likely have small home ranges, as do other rockfish [13-15].

During June and July of 2011, 2012, and 2013, yelloweye rockfish were captured off the east $(n=28)$ and west $(n=25)$ coasts of Prince of Wales Island (Figure 1), using rod and reel. Fish were euthanized immediately after capture. Total length and wet weights (total and liver) were recorded, and samples of axial muscle, liver, and spleen tissues were collected. Length $(\mathrm{cm})$, weight $(\mathrm{g})$, and liver weight $(\mathrm{g})$ were used to calculate condition factor and hepatosomatic index (HSI) according to the following formulas

$$
\text { Condition factor }=\frac{1000 \times \text { weight }}{\text { length }^{3}}
$$

$$
\text { Hepatosomatic index }=\left(\frac{\text { liver weight }}{\text { weight }}\right) \times 100
$$

Subsamples of tissues for elemental analysis were placed in individual plastic bags and frozen at $-20^{\circ} \mathrm{C}$. Subsamples of liver and spleens for histological analyses were fixed in neutral buffered formalin and later transferred to $70 \%$ ethanol for storage. Sagittal otoliths were collected for age analysis, which was performed at the Alaska Department of Fish and Game Age Determination Unit, using the break-and-burn method [12].

\section{Elemental analysis}

Frozen tissue samples were lyophilized to constant weight and homogenized. Total $\mathrm{Hg}$ was analyzed in the homogenized samples with a direct $\mathrm{Hg}$ analyzer (DMA-80, Milestone). Quality assurance included reference and duplicate samples. The $\mathrm{Hg}$ concentrations in reference materials were within certified ranges, and the mean relative percent difference of duplicate samples of muscle, liver, and spleen were $0.58 \%$, $1.43 \%$, and $0.97 \%$, respectively.

A more in-depth description of the method of $\mathrm{Hg}(\mathrm{II})$ analysis is presented in Barst et al. [16]. Briefly, tissues were digested in $\mathrm{HCl}$ with microwave heating, and organic $\mathrm{Hg}$ was extracted with toluene. The acidic fraction remaining after toluene extraction of the original digestate was diluted 5-fold with reagent grade water, and an aliquot was added to a quartz analytical vessel for quantification of ionic $\mathrm{Hg}$ with a DMA-80.

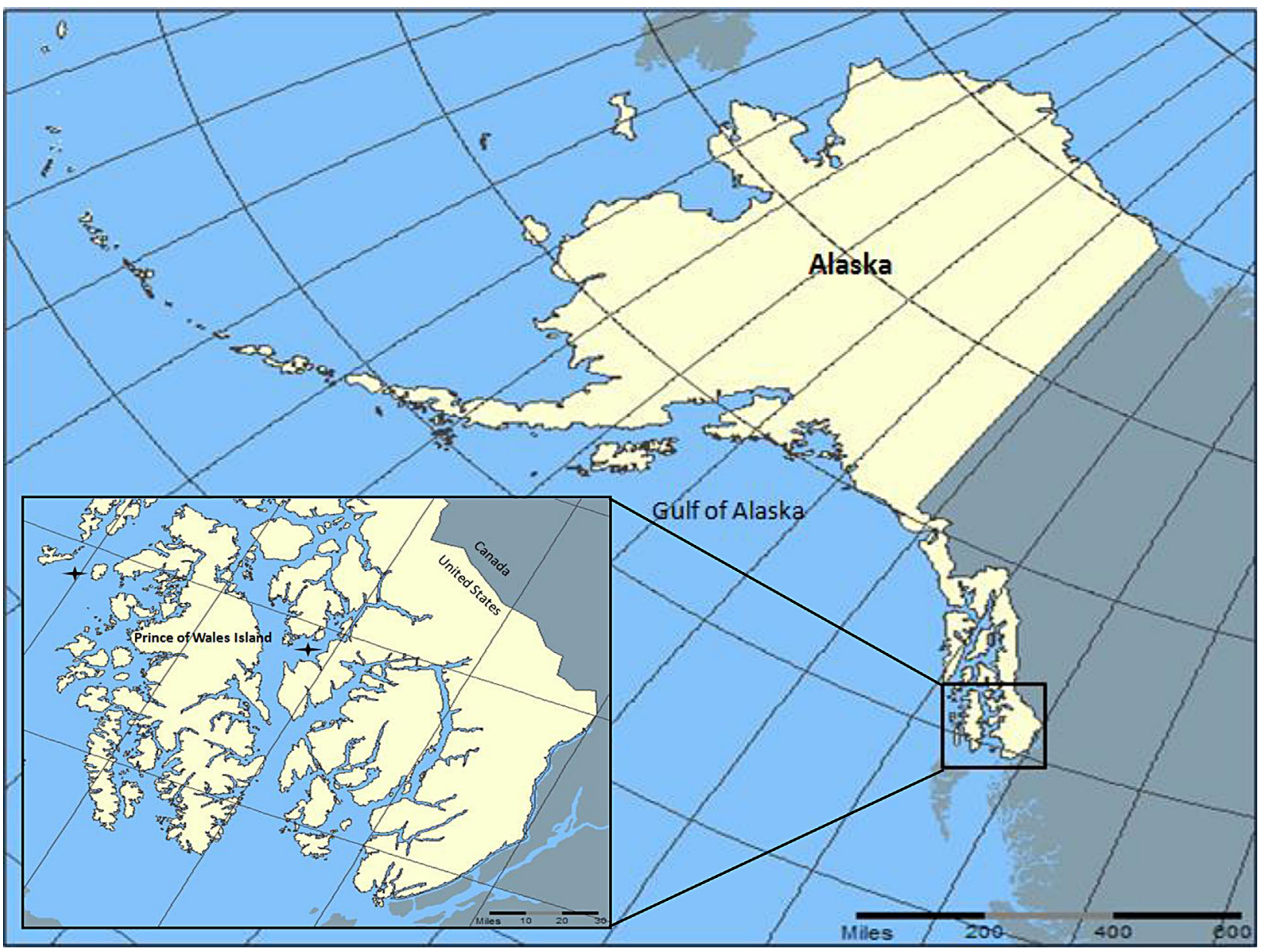

Figure 1. Location of Prince of Wales Island, Alaska, USA. The black symbols in the inset image show the locations of the 2 sampling sites. 
Methylmercury was calculated by subtracting $\mathrm{Hg}$ (II) from total $\mathrm{Hg}$ of the same sample. The mean recovery of a digested reference material was $99.14 \%(n=7)$, and the mean relative percent difference of duplicate samples of liver and spleen were $0.74 \%$ and $1.22 \%$ respectively.

Metals ( $\mathrm{Se}, \mathrm{Ni}, \mathrm{Cd}, \mathrm{Cu}$, and $\mathrm{Zn}$ ) were measured by digesting lyophilized subsamples of liver with concentrated $\mathrm{HNO}_{3}$ (Aristar grade) followed by $30 \%(\mathrm{w} / \mathrm{w})$ hydrogen peroxide (Trace Select Ultra grade). Ultrapure water was added to the digestates to reach a $10 \% \mathrm{HNO}_{3}$ concentration before analysis by inductively coupled plasma-mass spectrometry (ICP-MS; Thermo Elemental $\mathrm{X}$ Series). Certified reference material (lobster hepatopancreas, TORT-3, National Research Council of Canada) was subjected to the same digestion procedure and analysis. Recoveries of metals in the reference material were within certified ranges. Spleens and muscle samples were not analyzed for metals other than $\mathrm{Hg}$.

\section{Melano-macrophage aggregates}

Both spleen and fixed liver tissues were embedded in paraffin, sectioned, and mounted on glass slides. Seven-micron sections were stained with hematoxylin and eosin and viewed under light microscopy (Axiovert 200; Zeiss Microscopy) to evaluate general pathology. Each of 3 fields of view, at $100 \times$ magnification, was photographed (Axiocam HRc, Zeiss Microscopy) for each hematoylin and eosin-stained liver and spleen. The mean percent coverage of MA, in relation to the total area of the field of view, was calculated by using Image $\mathbf{J}$ software [17]. Alternate unstained sections were archived for LA-ICP-MS $(20 \mu \mathrm{m})$ analysis and X-ray fluorescence imaging (7 $\mu \mathrm{m})$.

\section{LA-ICP-MS and X-ray fluorescence imaging}

Tissue sections were used to investigate the distribution of metals in yelloweye liver sections by LA-ICP-MS, according to the methods of Barst et al. [10] with slight modification. Briefly, a microscope slide with unstained, paraffin-embedded tissue was placed into the chamber of a 213-nm Nd:YAG laser ablation source (New Wave Research). A charge-coupled device camera enabled zooming and scanning of the slide to locate the tissue. Three areas of normal liver tissue and 3 MA were chosen at random and ablated from sections representing individual yelloweye $(n=21)$ with a $55-\mu \mathrm{m}$ beam diameter. A Varian 820 ICP-MS coupled to the laser source was used to monitor $\mathrm{Hg}, \mathrm{Se}, \mathrm{Cd}, \mathrm{Ni}, \mathrm{Cu}$, and $\mathrm{Zn}$. The mean isotope counts of each element during laser warmup were used as an estimate of background noise and subtracted from the mean counts for the remainder of the run to calculate a signal. After ablation, slides were viewed again under light microscopy to ensure that MA were accurately targeted [10]. Table S1 in the Supplemental Data describes the instrument parameters used for analysis.

$\mathrm{X}$-ray fluorescence images of a yelloweye liver section (mounted in paraffin on a Thermanox plastic coverslip) were collected at the Advanced Photon Source, Argonne National Laboratory with beamline 20-ID-BD (PNC/XOR). The incident $\mathrm{X}$-ray energy was kept at $13.45 \mathrm{keV}$, and the $7.0 \mathrm{GeV}$ storage ring was operated in continuous top-up mode at $102 \mathrm{~mA}$. Beam focusing and harmonic rejection were accomplished with an Si(111) double crystal monochromator and rhodium-coated silicon mirrors. Incident X-rays were measured by using the intensity of the nitrogen-filled ion chambers. Kilpatrick-Baez rhodium-coated focusing mirrors produced a microfocused beam of $5 \mu \mathrm{m}$ diameter. The sample was mounted at 45 degrees to the incident X-ray beam and was spatially rastered in the microbeam with a step size of $5 \mu \mathrm{m}$ and a beam exposure of $0.5 \mathrm{~s}$ per step. The intensities of the X-ray fluorescence lines $(\mathrm{Hg} \mathrm{L} \alpha$, $\mathrm{Se} \mathrm{K} \alpha, \mathrm{Cu} \mathrm{K} \alpha$, and $\mathrm{Zn} \mathrm{K} \alpha$ ) at each step were monitored using a 4-element silicon-drift Vortex detector (SII NanoTechnology USA). Data were processed using SMAK software. Windowed $\mathrm{X}$-ray fluorescence counts were normalized by the incident $\mathrm{X}$ ray intensity and background corrected by subtracting the average intensity obtained from pixels outside the tissue. Quantities of Se and $\mathrm{Zn}$ per pixel were directly calibrated by measuring the respective X-ray fluorescence calibration standard, which was deposited as a thin layer on $6.3-\mu \mathrm{m}$-thick Mylar film $\left(56.7 \mu \mathrm{g} / \mathrm{cm}^{2}\right.$ of Se and $20 \mu \mathrm{g} / \mathrm{cm}^{2}$ of ZnTe). The quantity of $\mathrm{Hg}$ per pixel was calibrated with 2 X-ray fluorescence thin standards $\left(50.8 \mu \mathrm{g} / \mathrm{cm}^{2} \mathrm{Au}\right.$ and $53.1 \mu \mathrm{g} / \mathrm{cm}^{2}$ $\mathrm{TlCl}$ on 6.3- $\mu \mathrm{m}$-thick Mylar film (Micromatter). Elemental $\mathrm{Hg}$ is volatile; therefore, $\mathrm{Tl}$ and $\mathrm{Au}$, elements adjacent to $\mathrm{Hg}$ in the periodic table, were used for calibration. Average background intensities for windowed fluorescence from the standards were estimated from the X-ray fluorescence image of the $6.3-\mu \mathrm{m}$ thick Mylar film. The background-corrected $\mathrm{Au}$ and $\mathrm{Tl} \mathrm{L} \alpha$ fluorescence intensities were used to interpolate the $\mathrm{Hg}$ L $\alpha$ fluorescence intensity, which was then applied to the background-corrected $\mathrm{Hg}$ distribution map to obtain the quantity of $\mathrm{Hg}$ per pixel in $\mu \mathrm{g} / \mathrm{cm}^{2}$ [18]. Unfortunately, we were not able to determine the $\mathrm{Cd}$ concentration in the yelloweye liver section with X-ray fluorescence, because the energy of the $\mathrm{Cd} L \alpha$ overlaps with that of $\mathrm{Ar} \mathrm{K} \alpha$ photons present in air. In addition, a $\mathrm{Cu}$ standard was not available, so $\mathrm{Cu}$ data are presented as normalized $\mathrm{Cu} \mathrm{K} \alpha$ fluorescence counts. Nickel was not detected by X-ray fluorescence in the yelloweye liver section because of the low concentration of this metal in the tissue.

\section{Statistical analyses}

Statistics were performed with JMP 9 Statistical Analysis Software (SAS Institute). Data transformations, such as log or arcsine, were employed if necessary, to meet the assumptions of tests. Linear regression models were used to describe relationships between variables. The residuals of the linear regression models were tested for normality and tested to determine whether outliers had biased the coefficients of determination. Levene's test was used to determine unequal variances. Concentrations of total $\mathrm{Hg}$ (in muscle, liver, and spleen) were compared between sampling sites after correcting for fish length. This was carried out by comparing the residuals obtained from linear regressions between $\log$ total $\mathrm{Hg}$ and fork length with two-sample $t$-tests. Two-sample $t$-tests were also used to determine differences in hepatic concentrations of $\mathrm{Se}, \mathrm{Ni}, \mathrm{Cd}$, $\mathrm{Cu}$, and $\mathrm{Zn}$ between sites. The residuals, after regression of liver MA percentage coverage and fish age, were included with metal concentrations in a stepwise linear regression model. Because only $\mathrm{Hg}$ was measured in spleens, a stepwise regression was carried out only for data obtained from yelloweye livers. Yelloweye rockfish growth curves were compared with Tukey's honest significance difference test. Significance of statistical tests was determined with a type I error $(\alpha)$ of 0.05 .

\section{RESULTS}

\section{Metal concentrations in fish tissues}

Mean concentrations of metals in yelloweye tissues are presented in Table 1. All concentrations are reported as mean values in micrograms per gram wet weight \pm standard deviation (SD). Total $\mathrm{Hg}$ concentrations, in all fish, were highest in liver 
Table 1. Mean metal concentrations ( $\mu \mathrm{g} / \mathrm{g}$ wet wt) in tissues of yelloweye rockfish (Sebastes ruberrimus) from Prince of Wales Island, Alaska, USA ${ }^{\mathrm{a}}$

\begin{tabular}{|c|c|c|c|c|c|c|c|c|}
\hline \multirow[b]{2}{*}{ Sampling area } & \multirow{2}{*}{$\begin{array}{c}\text { Muscle } \\
\text { Total Hg }\end{array}$} & \multirow{2}{*}{$\begin{array}{c}\text { Spleen } \\
\text { Total Hg }\end{array}$} & \multicolumn{6}{|c|}{ Liver } \\
\hline & & & Total Hg & $\mathrm{Se}$ & $\mathrm{Ni}$ & $\mathrm{Cd}$ & $\mathrm{Cu}$ & $\mathrm{Zn}$ \\
\hline West & $0.44 \pm 0.24^{* * *}$ & $0.56 \pm 0.47^{* * *}$ & $0.7 \pm 0.55^{* *}$ & $2.7 \pm 0.83$ & $0.04 \pm 0.023$ & $2.0 \pm 0.99^{*}$ & $3.2 \pm 1.38^{* * *}$ & $20.0 \pm 2.57^{* *}$ \\
\hline
\end{tabular}

${ }^{a}$ Asterisks note significant differences between sampling sites.

$p<0.05$.

$p<0.001$.

$p<0.0001$

samples $(0.87 \pm 0.75)$, intermediate in spleen $(0.71 \pm 0.60)$, and lowest in muscle $(0.52 \pm 0.30)$. The predominant form of $\mathrm{Hg}$ in both livers and spleens was $\mathrm{Hg}(\mathrm{II})$, constituting $58 \%$ and $73 \%$, respectively, of the total $\mathrm{Hg}$ concentrations in these organs. Fish length was positively correlated with concentrations of total $\mathrm{Hg}$ in liver $\left(r^{2}=0.27, p<0.0001\right)$, spleen $\left(r^{2}=0.35, p<0.0001\right)$, and muscle $\left(r^{2}=0.36, p<0.0001\right)$. Fish from the eastern sampling site had significantly higher $\mathrm{Hg}$ concentrations in muscle (2-sample $t$-test, $p<0.0001)$, liver $(p=0.0001)$, and spleen $(p<0.0001)$.

Liver Se was positively correlated with total $\mathrm{Hg}\left(r^{2}=0.60\right.$, $p<0.0001$, Se to $\mathrm{Hg}$ mean molar ratio of $2.2 \pm 1.54$ ), and concentrations were similar between fish from the east and west coast s. Nickel concentrations were low $(0.035 \pm 0.023)$ in all yelloweye livers and did not differ significantly between the populations. However, the mean liver concentrations of $\mathrm{Cd}, \mathrm{Cu}$, and $\mathrm{Zn}$ were significantly higher in the livers of yelloweye sampled from the east coast of Prince of Wales Island (Table 1). Of the metals measured in yelloweye livers, only $\mathrm{Hg}\left(r^{2}=0.55\right.$, $p<0.0001)$, Se $\left(r^{2}=0.27, p<0.0001\right)$, and $\mathrm{Cd}\left(r^{2}=0.33\right.$, $p<0.0001)$ were positively correlated with fish age.

\section{Melano-macrophage aggregate area}

Melano-macrophage aggregates were identified by fluorescence and light microscopy in both the livers and spleens of yelloweye rockfish and contained lipofuscin, hemosiderin, and melanin pigments (Figure 2). During preliminary histological analyses, a qualitative difference in MA size was noted, which led to the proposed use of imaging software to quantify

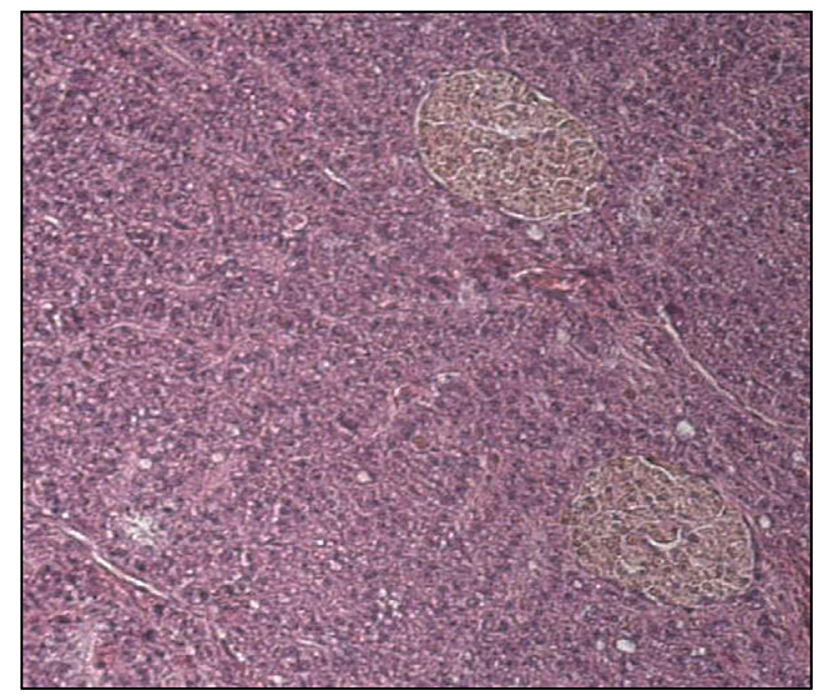

Figure 2. Micrograph of a yelloweye liver section at $100 \times$ magnification showing pink hepatocytes and brown melano-macrophage aggregates. macrophage area. Image analysis software for the quantification of fish MA has been performed previously by Schwindt et al. [19], who used ImagePro Plus, and Mizuno et al. [20], who used NIH Image (Ver 1.57). We opted to use Image J software, which has replaced NIH Image and is free to download from the National Institutes of Health. In general, MA were larger and more prevalent in spleens (mean coverage $=6.2 \%$ ) than in liver (mean coverage $=1.1 \%$, which could be because of the increased turnover of erythrocytes in the organ [21]. Fish age was positively correlated with MA area in both liver $\left(r^{2}=0.49\right.$, $p<0.0001)$ and spleen $\left(r^{2}=.41, p<0.0001\right)$. The metal explaining most of the variance in hepatic MA was $\mathrm{Hg}$ (II) $\left(r^{2}=0.64, p<0.0001\right)$. Positive correlations were also noted between hepatic MA area and concentrations of total $\mathrm{Hg}$ $\left(r^{2}=0.62, p<0.0001\right), \mathrm{MeHg}\left(r^{2}=0.51, p<0.0001\right), \mathrm{Se}$ $\left(r^{2}=0.35, p<0.0001\right), \mathrm{Cd}\left(r^{2}=0.41, p<0.0001\right)$, and $\mathrm{Cu}$ $\left(r^{2}=0.09, p=0.044\right)$. Inorganic $\mathrm{Hg}$ also better explained MA area $\left(r^{2}=0.59, p<0.0001\right)$ than $\mathrm{MeHg}$ in the spleens of yelloweye. No significant difference in MA area was found between the 2 sampling sites in either liver (2-sample $t$-test, $p=0.57$ ) or spleen (2-sample $t$-test, $p=0.97$ ). An increase in MA size attributable to aging has been previously reported [2] and presumably occurs because of increased phagocytosis of effete cells. Therefore, accounting for fish age is important when determining the association between MA area and concentrations of metals. By including the effects of fish age and concentrations of metals in a model, we determined that $\mathrm{Hg}(\mathrm{II})$ was still the best predictor of MA area (stepwise regression, $\left.r^{2}=0.33, p<0.0001\right)$.

\section{Metals in hepatic melano-macrophage aggregates}

Counts of $\mathrm{Hg}, \mathrm{Se}, \mathrm{Cd}$, and $\mathrm{Cu}$ were consistently higher in MA than adjacent hepatocytes, indicating that MA accumulate these metals to a greater degree than the surrounding tissue. In $95 \%$ of the ablated MA, $\mathrm{Hg}$ counts were higher than the surrounding hepatocytes. Selenium, $\mathrm{Cd}$, and $\mathrm{Cu}$ were higher in $67 \%, 76 \%$, and $71 \%$ of the ablated MA compared with nearby hepatocytes. Counts of Ni were low in all ablated regions, barely rising above background in most cases. Counts of $\mathrm{Zn}$ were higher in MA than hepatocytes for less than half (43\%) of the ablations. We calculated the ratio of metal in MA relative to the surrounding normal tissue $\left(\mathrm{M}_{\mathrm{MA}}: \mathrm{M}_{\mathrm{Hep}}\right)$ for $\mathrm{Cu}, \mathrm{Zn}, \mathrm{Cd}, \mathrm{Hg}$, and Se. Mercury had the highest mean $\mathrm{M}_{\mathrm{MA}}: \mathrm{M}_{\mathrm{Hep}}$ ratio at 2.73 , followed by $\mathrm{Se}$ (2.71), $\mathrm{Cu}$ (1.87), $\mathrm{Cd}$ (1.53), and $\mathrm{Zn}$ (0.98). The order of these ratios, determined by LA-ICP-MS, is supported by X-ray fluorescence data gathered from the analysis of a yelloweye liver (Figure 3).

\section{Condition indices}

We assessed the physical condition of yelloweye in the present study by calculating 2 indices. These were the condition 


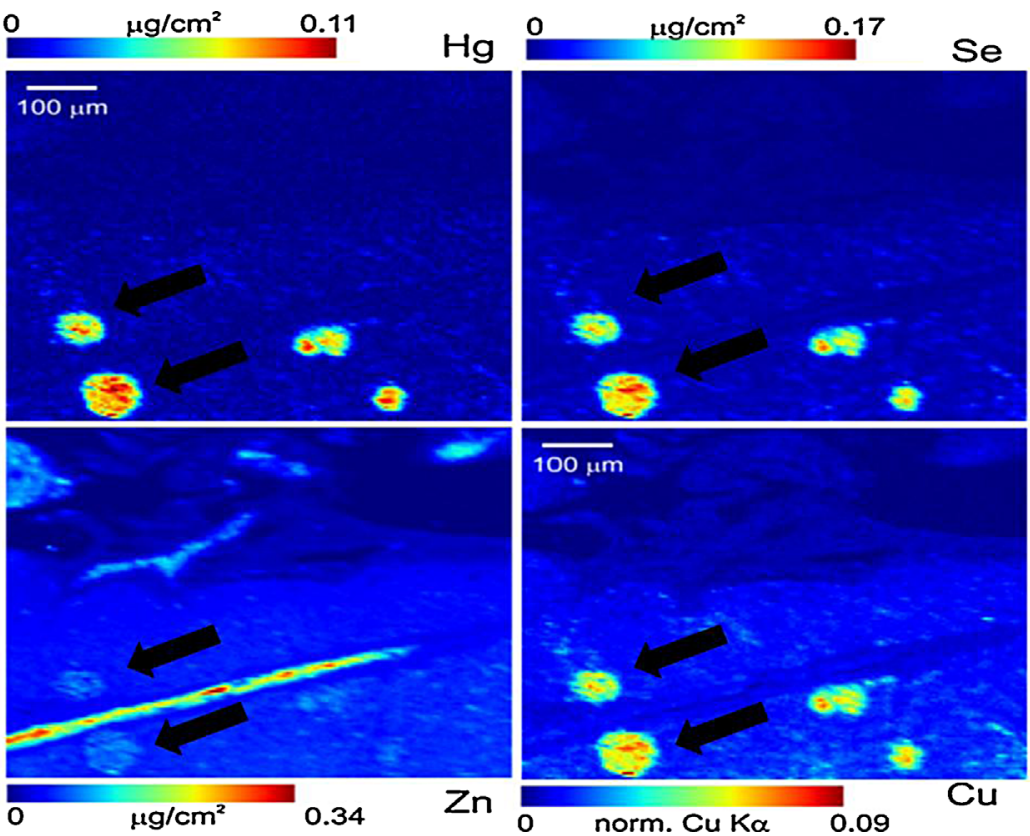

Figure 3. X-ray fluorescence images of a yelloweye rockfish liver section. The black arrows mark the positions of the melano-macrophage aggregates.

factor, which relates body length and weight, and the hepatosomatic index, which gives the weight of the liver relative to the total weight of the fish. In the present study, body condition was not significantly correlated with concentrations of any of the metals and did not differ between males (mean $=1.60)$ and females (mean =1.72). However, condition factor was significantly higher in fish from the western sampling area $($ mean $=1.71)$ than in fish from the eastern area $($ mean $=1.55$; 2-sample $t$-test, $p=0.003$ ).

Mean HSI was significantly lower in female $($ mean $=0.83)$ than male $($ mean $=1.35$ ) yelloweye ( 2 -sample $t$-test, $p=0.003$ ). The HSI is sensitive to differences in the relative weights of male and female gonads. An energetic tradeoff occurs between liver investment and gonad investment (e.g., Merrill and Collins [22]), and ovaries require a bigger investment than testes. Therefore, a larger relative gonad weight for female yelloweye is the most likely cause for the lower HSI in female fish. Like body condition index, HSI was significantly greater in fish from the western sampling area $($ mean $=1.42)$ than in those from the eastern area (mean $=1.10 ; 2$-sample $t$-test, $p=0.034)$. When regressing metal concentrations with HSI, all male fish were pooled together and then analyzed separately based on sampling site. For all male fish, HSI was negatively correlated with concentrations of $\mathrm{Cu}\left(r^{2}=0.29 ; p=0.0004\right), \quad \mathrm{Zn}$ $\left(r^{2}=0.37 ; p<0.0001\right), \mathrm{Cd}\left(r^{2}=0.20 ; p=0.005\right)$, and $\mathrm{Se}$ $\left(r^{2}=0.21 ; p=0.003\right)$. Only Se $\left(r^{2}=0.60 ; p=0.008\right)$ was significantly negatively correlated with HSI in female fish, although the significance of the other relationships may have been hampered by a low sample size $(n=11)$.

For males from the western sampling site, HSI significantly decreased with increasing concentrations of $\mathrm{Cu}\left(r^{2}=0.65\right.$; $p<0.0001)$, Zn $\left(r^{2}=0.68 ; p<0.0001\right)$, and Se $\left(r^{2}=0.34\right.$; $p=0.012$ ). Only $\mathrm{Cd}$ was negatively correlated with HSI in males from the eastern sampling location $\left(r^{2}=0.22 ; p=0.03\right)$. The HSI was negatively correlated with $\mathrm{Zn} \quad\left(r^{2}=0.95\right.$; $p=0.0010$ ) for female fish from the eastern sampling site; however, no significant correlations were found between metals and HSI for females from the west.

\section{DISCUSSION}

Metal concentrations in fish tissues

The reason for higher concentrations of hepatic $\mathrm{Hg}, \mathrm{Cd}, \mathrm{Cu}$, and $\mathrm{Zn}$ in yelloweye from the eastern sampling site is unknown, but it may be linked to higher exposure concentrations, differences in growth rate, or differences in fish condition. Although we did not measure concentrations of metals in water, Ernest Sound may receive greater terrestrial inputs of metals, resulting in higher exposure concentrations. Geologic deposits of $\mathrm{Cu}$ and $\mathrm{Zn}$, which contain deposits of $\mathrm{Cd}$ [23], are present on Prince of Wales Island and in other parts of Alaska's Inside Passage [24] and have been historically mined in the area [25]. In contrast to the sampling site in Ernest Sound, the western sampling site is not surrounded by land and therefore would not be expected to receive as much terrestrial runoff. Hepatic metals contents also may vary because of differences in growth rate between the 2 samples. Although no significant difference in mean fish age was found between the 2 sites (2-sample $t$-test, $p=0.37$ ), the growth rate, determined by length and age distributions, differed between groups. The Alaska Department of Fish and Game routinely collect measurements of length and age from yelloweye caught by commercial fishers in Alaskan waters. Length versus age plots for yelloweye captured by commercial fishers from both the inside $(n=5504)$ and outside $(n=7790)$ waters of Southeastern Alaska are presented in Figure 4 . The 25 individuals from the eastern (inside) waters and the 23 individuals from the western (outside) waters are also plotted in this graphic. The von Bertalanffy growth curves for the 2 larger datasets are not significantly different, suggesting that overall fish from the outside and inside populations have similar growth rates. However, the 2 growth curves based solely on the fish sampled in the present study are significantly different $(p=0.005)$. The 25 fish from the eastern sampling site fall within the age/length distribution of the Alaska Department of Fish and Game inside waters dataset. However, the 23 fish sampled from the western site near Coronation Island exhibit a localized size grouping that is not representative of the entire 

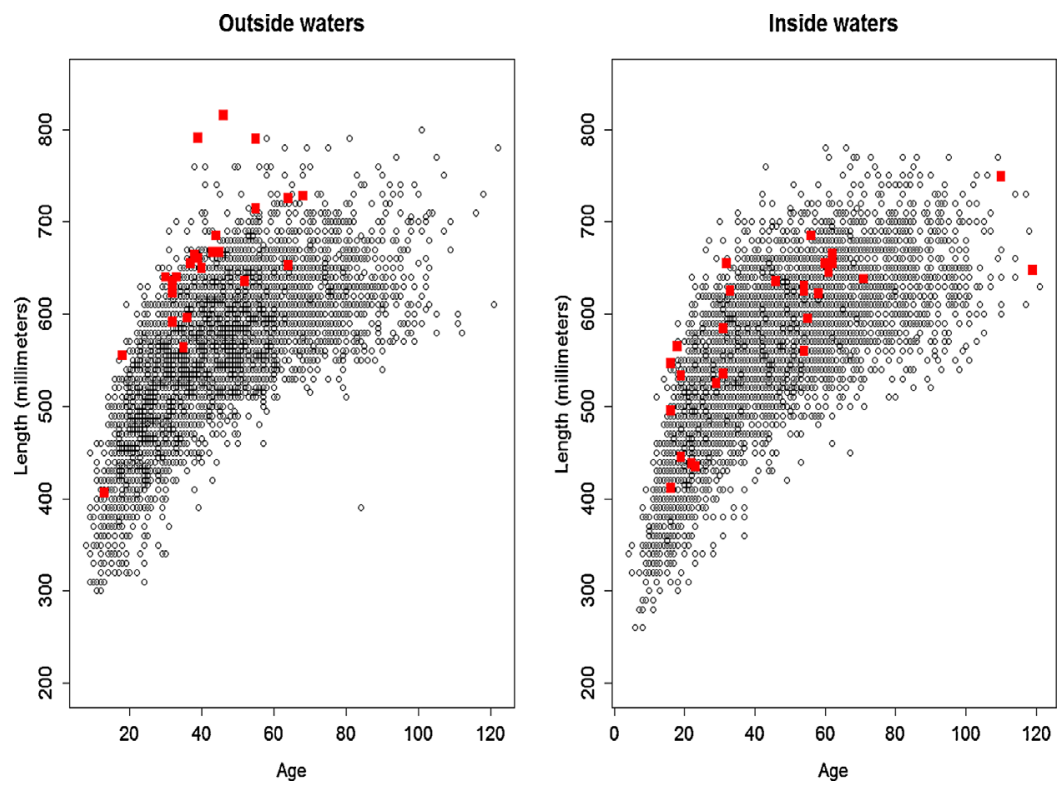

Figure 4. Length and age distributions for yelloweye rockfish captured from the outside (left) and inside (right) waters of southeast Alaska. The red markers indicate fish from the western (left) and eastern (right) sampling sites for the present study.

population of yelloweye from the outside waters. Size and growth rates of yelloweye rockfish may vary greatly between localized sampling sites based on differences in temperature and nutrient availability across their range. An increase in growth rate has been linked to decreased $\mathrm{Hg}$ concentrations by means of somatic growth dilution in aquatic invertebrates and fish $[26,27]$. We tested whether $\mathrm{Hg}$ concentrations in yelloweye tissues decreased because of increased growth rate by regressing the residuals of linear regressions between length and age and length and $\log \mathrm{Hg}$ concentrations. The lack of any significant negative relationships resulting from these regressions indicates that differences in $\mathrm{Hg}$ concentrations between the 2 sampled populations are unlikely to be caused by growth dilution.

\section{Condition indices}

Correlations between condition factor and metal concentrations in fish tissues vary throughout the literature. For example, Rajotte and Couture [28] documented lower condition in yellow perch from metal-contaminated lakes near Sudbury, Ontario. No differences in condition factor were reported for rainbow trout exposed to runoff from $\mathrm{Cu}$ mine tailings [29] or for lake whitefish (Coreogonus clupeaformis) exposed to dietary nickel [30]. Drevnick et al. [31] noted a decreased condition factor of northern pike (Esox lucius) with higher Hg concentrations. In wild fish, multiple factors may contribute to changes in body condition, including food availability, temperature, and contaminants [32]. Importantly, yelloweye body condition is unlikely to be linked to differences in metal body burdens, because none of the metals were correlated with fish condition.

The HSI is a more specific index than body condition, because it may demonstrate an effect on the liver, which is often a target of contaminants because of its role as a detoxification organ. Changes in HSI indicate decreases in energy reserves and altered metabolism in fish, both of which may be the targets of toxic chemicals [33]. Similar to body condition, reports of how HSI correlates to metals exposure differ. The HSI decreased with increasing $\mathrm{Cd}$ concentration in the livers of winter flounder (Pleuronectes americanus) after an aqueous exposure for $71 \mathrm{~d}$ [34]. Decreases in HSI also have been reported for gray mullet (Chelon labrosus) fed Cu-containing diets [35] and for wild walleye (Sander vitreus) with elevated $\mathrm{Hg}$ concentrations [36]. The HSI also has been shown to increase in fish from contaminated sites, presumably resulting from cellular hypertrophy $[32,37]$. Other studies have documented nonsignificant correlations between HSI and metal tissue concentrations $[38,39]$. Differences in the results regarding HSI and body condition are likely dependent on the types of contaminants present, the species of fish, and exposure duration/pathway, as well as other environmental factors, including food availability.

Taken together, the elevated growth rate, HSI, and body condition of the yelloweye from the western site are likely a result of greater temperatures or food availability. Increased food availability boosts hepatic reserves of lipids and glycogen, thus increasing the relative weight of the liver and overall body condition. Yelloweye with fewer energy stores in the liver would likely have higher metal contents because of the concentrating effect of lipid removal. This has been reported in other studies $[31,40]$ and may explain the elevated hepatic metal contents in yelloweye from the eastern sampling site.

\section{Melano-macrophage aggregates}

The colocalization of MA and metals has been documented in previous studies. Pulsford et al. [41] noted the presence of 19 metals in MA in kidney and spleen of flounder (Platichthys flesus) by X-ray microanalysis. Woshner et al. [42] used autometallography to show that in the livers of beluga whales (Delphinapterus leucas), $\mathrm{Hg}$ was within stellate macrophages. Barst et al. [10] noted elevated relative concentrations of both $\mathrm{Hg}$ and $\mathrm{Se}$ in the hepatic MA of spotted gar from Caddo Lake. Most recently, $\mathrm{Hg}$ was also demonstrated to accumulate in the MA of yellow perch by Batchelar et al. [11], who noted that $\mathrm{Hg}$ was on average $2.45 \times$ higher in MA than in hepatocytes. Similar to Batchelar et al. [11], we calculated the ratio of metal in MA relative to the surrounding normal tissue for $\mathrm{Cu}, \mathrm{Zn}, \mathrm{Cd}$, $\mathrm{Hg}$, and Se. Mercury had the highest mean $\mathrm{M}_{\mathrm{MA}}: \mathrm{M}_{\mathrm{Hep}}$ ratio at 2.73, which was similar to the ratio reported by Batchelar et al. [11]. The mean $S e M_{M A}: M_{N o r m}$ ratio was 2.71 , followed by $\mathrm{Cu}$ (1.87), $\mathrm{Cd}$ (1.53), and $\mathrm{Zn}$ (0.98). The order of these ratios, determined by LA-ICP-MS, is supported by X-ray fluorescence data gathered from the analysis of a yelloweye liver (Figure 3 ). 
The accumulation of metals in MA may be caused by the phagocytosis of cells that are dead or dying as a result of metal toxicity or because some metals are needed for the normal functioning of these immune cells. Copper, $\mathrm{Zn}$, and Se are micronutrients, often incorporated into the active sites of enzymes; however, in excess, these metals may be toxic [43]. Both $\mathrm{Cu}$ and $\mathrm{Zn}$ are found in $\mathrm{CuZn}$ superoxide dismutase (SOD), an important antioxidant enzyme that accelerates the conversion of superoxide radicals to hydrogen peroxide and oxygen [32]. Superoxide dismutase has been shown to increase phagocytic activity of macrophages in mice [44] and also may be up-regulated in the MA of fish. Furthermore, impaired respiratory burst has been documented in $\mathrm{Cu}$-deficient rats [45] and has been linked to decreased $\mathrm{CuZn-SOD}$ activity in bovine macrophages [46], suggesting that these metals are necessary for the normal functioning of these cells. Conversely, neither $\mathrm{Hg}$ nor $\mathrm{Cd}$ have any known biological function; therefore, their presence in MA is more likely a result of metal-induced cellular damage.

Selenium is an essential nutrient that is incorporated into selenocysteine and selenoproteins, including glutathione peroxidase, which, along with glutathione and glutathione reductase, make up an extremely important cellular antioxidant defense system [47]. Like CuZn-SOD, the glutathione system plays an important role in the protection of macrophages from self-induced oxidative injury. Selenium's protective effect from $\mathrm{Hg}$ toxicity has been previously reported in the literature [4850], and a 1:1 molar ratio between the 2 is assumed to result in an inert $\mathrm{HgSe}$ compound [50]. In excess, $\mathrm{Hg}$ may result in a deficiency of Se needed to produce selenoenzymes [51]. Neither LA-ICP-MS nor X-ray fluorescence provides information about the exact chemical form of $\mathrm{Hg}$ or $\mathrm{Se}$ in MA. However, 58\% of the total $\mathrm{Hg}$ in yelloweye livers was $\mathrm{Hg}$ (II), the best predictor of MA area. In addition, we noted significant correlations between both the $\mathrm{Se}$ and $\mathrm{Hg}$ concentrations in whole liver and the $\mathrm{Se}$ $\mathrm{M}_{\mathrm{MA}}: \mathrm{M}_{\mathrm{Hep}}$ ratio and counts of $\mathrm{Hg}$ in MA. Possibly $\mathrm{Hg}(\mathrm{II})$ is present in MA bound to Se. Mercury selenide is considered to be an inert end-product of $\mathrm{Hg}$ detoxification in marine mammals [42,52]; however, the end-product has not been identified in fish. Because we did not analyze other metals in yelloweye spleens, future work could focus on how metals are distributed in this organ. Further research is warranted to determine the role MA play in the storage of $\mathrm{Hg}$ and other metals.

\section{CONCLUSION}

In the present study, we noted an increased area of MA, a general biomarker of contaminant exposure, in the livers and spleens of yelloweye rockfish from Prince of Wales Island, Alaska. The variation in hepatic MA was best described by concentrations of $\mathrm{Hg}(\mathrm{II})$ even after accounting for other metals and the age of the fish, demonstrating that MA are excellent biomarkers of $\mathrm{Hg}$ exposure. The positive relationship between MA area and $\mathrm{Hg}$ concentration implies a dose-response relationship whereby cell damage increases with metal exposure. Higher relative concentrations of most metals were detected in MA, although $\mathrm{Hg}$ and Se tended to accumulate to a greater extent relative to surrounding hepatocytes. We hypothesize that $\mathrm{Hg}$ may be bound to $\mathrm{Se}$ in hepatic MA, resulting in the formation of an inert $\mathrm{HgSe}$ compound. Although we noted changes in tissues, we found no changes in HSI or body condition that were related to $\mathrm{Hg}$. Storage in hepatic MA removes $\mathrm{Hg}$ from circulation, reducing $\mathrm{Hg}$ exposure to other cells, tissues, and organs, and thus appears to protect against further $\mathrm{Hg}$ toxicity. Differences in metal concentrations between the 2 sampled populations could be attributable to differences in metal inputs to the 2 environments or to differences in food availability between the 2 groups of fish.

\section{SUPPLEMENTAL DATA}

Table S1. (11 KB DOC).

Acknowledgment-Funding was provided by Natural Sciences and Engineering Research Council Discovery Grant 371567-2009 (P. Drevnick). We greatly appreciate the assistance provided by the Griggers family and R. and M. Holley at TreeTops Lodge. We thank R. Gordon for assistance at the 20-ID beamline at the Advanced Photon Source and B. Bewer and K. Nienaber for synchrotron data collection. Sector 20 facilities operations at the Advanced Photon Source are supported by the US Department of Energy - Basic Energy Sciences, the Canadian Light Source, the University of Washington, and the Advanced Photon Source. Canadian Light Source is supported by the Canada Foundation for Innovation, Natural Sciences and Engineering Research Council of Canada, the University of Saskatchewan, the Government of Saskatchewan, Western Economic Diversification Canada, the National Research Council Canada, and the Canadian Institutes of Health Research.

Conflict of interest-The authors state no conflict of interest.

Data availability-Data are available on request. Please contact the corresponding author(drevnick@umich.edu).

\section{REFERENCES}

1. Wolke R. 1992. Piscine macrophage aggregates: A review. Annu Rev Fish Dis 2:91-108.

2. Agius C, Roberts R. 2003. Melano macrophage centres and their role in fish pathology. J Fish Dis 26:499-509.

3. McCarthy J, Shugart L. 1990. Biomarkers of Environmental Contamination. Lewis Publishers, Chelsea, MI, USA.

4. Capps T, Mukhi S, Rinchard JJ, Theodorakis CW, Blazer VS, Patiño R. 2004. Exposure to perchlorate induces the formation of macrophage aggregates in the trunk kidney of zebrafish and mosquitofish. J Aquat Anim Health 16:145-151.

5. Mela M, Randi M, Ventura D, Carvalho C, Pelletier E, Oliveira Ribeiro C. 2007. Effects of dietary methylmercury on liver and kidney histology in the neotropical fish Hoplias malabaricus. Ecotoxicol Environ Saf 68:426-435.

6. Giari L, Manera M, Simoni E, Dezfuli B. 2007. Cellular alterations in different organs of European sea bass Dicentrarchus labrax (L.) exposed to cadmium. Chemosphere 67:1171-1181.

7. Khan R. 2003. Health of flatfish from localities in Placentia Bay, Newfoundland, contaminated with petroleum and PCBs. Arch Environ Contam Toxicol 44:485-492.

8. Raldúa D, Bayona J, Barceló D. 2007. Mercury levels and liver pathology in feral fish living in the vicinity of a mercury cell chlor-alkali factory. Chemosphere 66:1217-1225.

9. Schwindt AR, Fournie JW, Landers DH, Schreck CB, Kent ML. 2008. Mercury concentrations in salmonids from western US national parks and relationships with age and macrophage aggregates. Environ Sci Technol 42:1365-1370.

10. Barst BD, Gevertz AK, Chumchal MM, Smith JD, Rainwater T, Drevnick P, Hudelson KE, Hart A, Verbeck GF, Roberts AP. 2011. Laser ablation ICP-MS co-localization of mercury and immune response in fish. Environ Sci Technol 45:8982-8988.

11. Batchelar KL, Kidd KA, Drevnick PE, Munkittrick KR, Burgess NM, Roberts AP, Smith JD. 2013. Evidence of impaired health in yellow perch (Perca flavescens) from a biological mercury hotspot in northeastern North America. Environ Toxicol Chem 32:627637.

12. MacLellan S, Station PB. 1997. How to Age Rockfish (Sebastes) Using S. Alutus as an Example, the Otolith Burnt Section Technique. Fisheries and Oceans Canada, Nanaimo, BC, Canada.

13. Yamanaka KL, Lacko L, Withler R, Grandin C, Lochead J, Martin J, Olsen N, Wallace S. 2006. A Review of Yelloweye Rockfish Sebastes ruberrimus Along the Pacific Coast of Canada: Biology, Distribution and Abundance Trends. Fisheries and Oceans Canada, Science, Nanaimo, BC, Canada. 
14. Matthews KR. 1990. A telemetric study of the home ranges and homing routes of copper and quillback rockfishes on shallow rocky reefs. Can J Zool 68:2243-2250.

15. Jorgensen SJ, Kaplan DM, Klimley A, Morgan SG, O'Farrell MR, Botsford LW. 2006. Limited movement in blue rockfish Sebastes mystinus: Internal structure of home range. Mar Ecol Prog Ser 327:157.

16. Barst BD, Hammerschmidt CR, Chumchal MM, Muir DC, Smith JD, Roberts AP, Rainwater TR, Drevnick PE. 2013. Determination of mercury speciation in fish tissue with a direct mercury analyzer. Environ Toxicol Chem 32:1237-1241.

17. Beaudin L, Johannessen SC, Macdonald RW. 2010. Coupling laser ablation and atomic fluorescence spectrophotometry: An example using mercury analysis of small sections of fish scales. Anal Chem 82:87858788.

18. Prince L, Korbas M, Davidson P, Broberg K, Rand MD. 2014. Target organ specific activity of Drosophila MRP (ABCC1) moderates developmental toxicity of methylmercury. Toxicol Sci 140:425-435.

19. Schwindt AR, Truelove N, Schreck CB, Fournie JW, Landers DH, Kent ML. 2006. Quantitative evaluation of macrophage aggregates in brook trout Salvelinus fontinalis and rainbow trout Oncorhynchus mykiss. Dis Aquat Org 68:101.

20. Mizuno S, Misaka N, Miyakoshi Y, Takeuchi K, Kasahara N. 2002. Effects of starvation on melano-macrophages in the kidney of masu salmon (Oncorhynchus masou). Aquaculture 209:247-255.

21. Fänge R, Nilsson S. 1985. The fish spleen: Structure and function. Experientia 41:152-158.

22. Merrill L, Collins PM. 2015. Environment and sex-specific allocation strategies among gonadal, somatic and immune indices in a marine fish. Can J Zool 93:207-212.

23. Ripley EA, Redmann RE. 1995. Environmental Effects of Mining. CRC, Boca Raton, FL, USA.

24. Robinson G, Twenhofel W. 1953. Some lead-zinc and zinc-copper deposits of the Ketchikan and Wales districts, Alaska. Bulletin 998-C. US Geological Survey, Washington, DC.

25. Wright CW, Wright C. 1907. Lode Mining in Southeastern Alaska. US Government Printing Office, Washington DC.

26. Karimi R, Chen CY, Pickhardt PC, Fisher NS, Folt CL. 2007. Stoichiometric controls of mercury dilution by growth. Proc Natl Acad Sci 104:7477-7482.

27. Ward DM, Nislow KH, Chen CY, Folt CL. 2010. Rapid, efficient growth reduces mercury concentrations in stream-dwelling Atlantic salmon. Trans Am Fish Soc 139:1-10.

28. Rajotte JW, Couture P. 2002. Effects of environmental metal contamination on the condition, swimming performance, and tissue metabolic capacities of wild yellow perch (Perca flavescens). Can J Fish Aquat Sci 59:1296-1304.

29. Dethloff G, Bailey H, Maier K. 2001. Effects of dissolved copper on select hematological, biochemical, and immunological parameters of wild rainbow trout (Oncorhynchus mykiss). Arch Environ Contam Toxicol 40:371-380.

30. Ptashynski M, Pedlar R, Evans R, Baron C, Klaverkamp J. 2002. Toxicology of dietary nickel in lake whitefish (Coregonus clupeaformis). Aquat Toxicol 58:229-247.

31. Drevnick P, Roberts A, Otter R, Hammerschmidt C, Klaper R, Oris J. 2008. Mercury toxicity in livers of northern pike (Esox lucius) from Isle Royale, USA. Comp Biochem Physiol C 147:331-338.

32. Di Giulio RT, Hinton DE. 2008. The Toxicology of Fishes. CRC, Boca Raton, FL, USA.

33. Van der Oost R, Beyer J, Vermeulen NP. 2003. Fish bioaccumulation and biomarkers in environmental risk assessment: A review. Environ Toxicol Pharmacol 13:57-149.

34. Pereira J, Mercaldo-Allen R, Kuropat C, Luedke D, Sennefelder G. 1993. Effect of cadmium accumulation on serum vitellogenin levels and hepatosomatic and gonadosomatic indices of winter flounder (Pleuronectes americanus). Arch Environ Contam Toxicol 24:427-431.

35. Baker R, Handy R, Davies S, Snook J. 1998. Chronic dietary exposure to copper affects growth, tissue lipid peroxidation, and metal composition of the grey mullet, Chelon labrosus. Mar Environ Res 45:357-365.

36. Larose C, Canuel R, Lucotte M, Di Giulio RT. 2008. Toxicological effects of methylmercury on walleye (Sander vitreus) and perch (Perca flavescens) from lakes of the boreal forest. Comp Biochem Physiol C 147:139-149.

37. Van Dyk J, Cochrane M, Wagenaar G. 2012. Liver histopathology of the sharptooth catfish Clarias gariepinus as a biomarker of aquatic pollution. Chemosphere 87:301-311.

38. Giguère A, Campbell PG, Hare L, McDonald DG, Rasmussen JB. 2004. Influence of lake chemistry and fish age on cadmium, copper, and zinc concentrations in various organs of indigenous yellow perch (Perca flavescens). Can J Fish Aquat Sci 61:1702-1716.

39. Berntssen M, Hylland K, Julshamn K, Lundebye AK, Waagbø R. 2004. Maximum limits of organic and inorganic mercury in fish feed. Aquacult Nutr 10:83-97.

40. Cizdziel J, Hinners T, Cross C, Pollard J. 2003. Distribution of mercury in the tissues of five species of freshwater fish from Lake Mead, USA J Environ Monit 5:802-807.

41. Pulsford A, Ryan K, Nott J. 1992. Metals and melanomacrophages in flounder, Platichthys flesus, spleen and kidney. J Mar Biol Assoc UK 72:483-498.

42. Woshner V, O'Hara T, Eurell J, Wallig M, Bratton G, Suydam R, Beasley V. 2002. Distribution of inorganic mercury in liver and kidney of beluga and bowhead whales through autometallographic development of light microscopic tissue sections. Toxicol Pathol 30:209.

43. Bertini I. 2007. Biological Inorganic Chemistry: Structure and Reactivity. University Science Books, Herndon, VA, USA.

44. Manni ML, Tomai LP, Norris CA, Thomas LM, Kelley EE, Salter RD, Crapo JD, Chang L-YL, Watkins SC, Piganelli JD. 2011. Extracellular superoxide dismutase in macrophages augments bacterial killing by promoting phagocytosis. Am J Pathol 178:2752-2759.

45. Babu U, Failla ML. 1990. Respiratory burst and candidacidal activity of peritoneal macrophages are impaired in copper-deficient rats. $J$ Nutr 120:1692-1699.

46. Cerone S, Sansinanea A, Streitenberger S, Garcia C, Auza N. 2000. Bovine monocyte-derived macrophage function in induced copper deficiency. Gen Physiol Biophys 19:49-58.

47. Rotruck J, Pope A, Ganther H, Swanson A, Hafeman DG, Hoekstra W. 1973. Selenium: Biochemical role as a component of glutathione peroxidase. Science 179:588-590.

48. Pařizek J, Ošt'ádalová I. 1967. The protective effect of small amounts of selenite in sublimate intoxication. Experientia 23:142-143.

49. Ganther H, Goudie C, Sunde M, Kopecky M, Wanger P, Hoh S, Hoekstra W. 1972. Selenium: Relation to decreased toxicity of methylmercury added to diets containing tuna. Science (Wash) 175:1122-1124.

50. Khan MAK, Wang F. 2009. Mercury selenium compounds and their toxicological significance: Toward a molecular understanding of the mercury selenium antagonism. Environ Toxicol Chem 28: 1567-1577.

51. Ralston NV, Blackwell III JL, Raymond LJ. 2007. Importance of molar ratios in selenium-dependent protection against methylmercury toxicity. Biol Trace Elem Res 119:255-268.

52. Martoja R, Berry JP. 1980. Identification of tiemannite as a probable product of demethylation of mercury by selenium in cetaceans: A complement to the scheme of the biological cycle of mercury. Vie Milieu 30:7-10. 